\title{
Systems of two immiscible liquids for a new type of membraneless fuel cells using renewable fuel
}

\author{
K.R. Tarantseva ${ }^{1, *}$, M.I. Yakhkind ${ }^{1}, A . K$. Mishra $^{2}$, M.A. Marynova ${ }^{1}$, E.A. Polyanskova $^{1}, A . A$. Goryacheva $^{1}$ \\ ${ }^{1}$ Penza State Technological University, Russia \\ ${ }^{2}$ University of South Africa, Johannesburg, Republic of South Africa
}

\begin{abstract}
Systems of two immiscible liquids are proposed for a new type of membraneless fuel cells using renewable fuel, in which the stationary phase boundary carries out a role of membrane. These systems consist of water, alcohol (preferable ethanol) and a number of electrolytes (salts and bases) leading to the layering of aqueous alcohol. In such systems top phase has significant alcohol content and insignificant electrolyte content, bottom phase has significant electrolyte content and insignificant alcohol content. To study the layering conditions in these systems, binodal curves were plotted for three two-phase liquid systems ( $\mathrm{EtOH}+\mathrm{K}_{2} \mathrm{CO}_{3}+\mathrm{H}_{2} \mathrm{O}$; EtOH $+\mathrm{K}_{3} \mathrm{PO}_{4}+\mathrm{H}_{2} \mathrm{O}$, EtOH $\left.+\mathrm{KOH}+\mathrm{H}_{2} \mathrm{O}\right)$, using the cloud point method. Comparison of our experimental data with the results of other authors showed that they are consistent for the first and second systems, and the temperature dependence of the binodal curves is clearly visible for the third system. The specific system EtOH $-30 \% \mathrm{~m} / \mathrm{m} ; \mathrm{KOH}-40 \% \mathrm{~m} / \mathrm{m} ; \mathrm{H}_{2} \mathrm{O}-30 \% \mathrm{~m} / \mathrm{m}$ was taken as the basis for studies of fuel cells based on two immiscible liquids. A further area of research lies in the field of optimizing the composition of both phases, studying the processes of mass transfer in these systems and their physicochemical characteristics.
\end{abstract}

\section{Introduction}

The transition to environmentally friendly and resourcesaving energetics and the creation of new energy sources is an urgent task of our time. Fuel cells (FCs), the operation of which is based on the direct transformation of chemical energy of fuel oxidation into electrical energy, avoiding ineffective combustion processes, may be one of its solutions.

Currently, of the various types of FCs using renewable fuels (alcohols, mainly ethanol), only membrane FCs have found practical use. In them there is a porous membrane with electrolyte between the anode and the cathode that conducts protons (cation-exchange, or proton-exchange, acid electrolyte) or hydroxide anions (anion-exchange, alkaline electrolyte), but does not conduct electrons $[1,2]$. Proton-exchange membranes are mainly used. The main problems of membrane FCs are associated with membranes and the use of expensive catalysts made of noble metals and alloys based on them.

Membranes are expensive enough and have limited working life. For cation-exchange membranes alkali accumulation on the cathode is observed that reduces efficacy of their work. For anion-exchange membranes formation of carbonates from alkaline electrolyte is observed. Diffusion of fuel through membranes and its loss due to chemical oxidation occurs too.

In acid media, the use of catalysts based on platinum, palladium and their alloys is necessary. Use of non- platinum catalysts is possible for alkaline electrolytes only.

Some of these limitations are absent in membraneless FCs or so-called co-laminar FCs proposed in the early 2000s. These FCs have narrow (less than $1 \mathrm{~mm}$ in diameter) micro-channels on whose walls the electrodes are applied [3-5]. In the channels two flows are fed fuel flow (usually solution of methanol, ethanol) and oxidant flow (solution of oxygen, hydrogen peroxide, potassium permanganate, etc.). No mixing of the flows due to their laminar character takes place, and the phase boundary carries out a role of membrane. The flows can be both acid (conductivity due to protons) and alkaline (conductivity due to hydroxide-anions). Versions are described where one of the flows is acid, and another is alkaline [4].

Absence of membrane and the problems associated with it is a main advantage of co-laminar FCs. But the complexity of their manufacture, the high cost, the relatively low power of separate cells, as well as the ability to work in the flow mode only are the reasons that till now these FCs can't compete with membrane FCs and haven't found practical use yet.

This work is devoted to the selection of electrolytes for a new type of membraneless FCs using renewable fuel. The stationary phase boundary of two immiscible liquids carries out a role of membrane in these FCs.

The selection of systems of immiscible liquids for the FCs was carried out based on the following requirements: two phases should not be mixed; both

\footnotetext{
* Corresponding author: $\underline{\operatorname{krtar} @, b k . r u}$
} 
phases should have electrical conductivity; one phase (anolyte) should have the maximum content of alcohol, the other phase (catholyte) should have the minimum content of alcohol.

Systems "water - electrolyte - lowest alcohol" can be examples of such immiscible liquids. It is known that the lowest alcohols $\left(\mathrm{C}_{1}-\mathrm{C}_{3}\right)$ are mixed with water in any ratios. However, when adding some salts or bases in water in enough high concentration, a separation of such system into two phases occurs [6]. Top phase has significant alcohol content and insignificant electrolyte content, bottom phase has significant electrolyte content and insignificant alcohol content.

For work of these FCs the top (alcohol) layer should contact with the anode, the bottom (aqueous) layer with the cathode, and oxidant should be added in it. Ethanol is considered as the main type of renewable fuel.

Systems "water - lower alcohol - hydrophobic ionic liquid" can be other examples of suitable immiscible liquids. It is known a series of hydrophobic ionic liquids not miscible with water and forming biphasic systems [7].

An analysis of the literature data for two-phase aqueous methanol-electrolyte systems showed that the list of electrolytes used is very limited and includes salts of 3 anions only [6, 8-10]:

- $\mathrm{KH}_{2} \mathrm{PO}_{4} / \mathrm{K}_{2} \mathrm{HPO}_{4}, \mathrm{~K}_{2} \mathrm{HPO}_{4}, \mathrm{~K}_{3} \mathrm{PO}_{4}$;

- $\mathrm{K}_{2} \mathrm{CO}_{3}, \mathrm{Rb}_{2} \mathrm{CO}_{3}$;

$-\mathrm{K}_{3} \mathrm{SbS}_{4}$.

From this list it can be concluded that only $\mathrm{K}^{+}$and $\mathrm{Rb}^{+}$are acceptable as cations in this case (the latter for carbonate).

For two-phase aqueous ethanol-electrolyte systems, the number of electrolytes used is noticeably larger. Their list includes salts of 8 inorganic anions (including all anions for aqueous methanol-electrolyte systems), as well as potassium and sodium hydroxides and salts of 2 organic anions [6, 9-20]:

- $\mathrm{KH}_{2} \mathrm{PO}_{4}, \mathrm{KH}_{2} \mathrm{PO}_{4} / \mathrm{K}_{2} \mathrm{HPO}_{4}, \mathrm{~K}_{2} \mathrm{HPO}_{4}, \mathrm{~K}_{3} \mathrm{PO}_{4}, \mathrm{~K}_{4} \mathrm{P}_{2} \mathrm{O}_{7}$, $\mathrm{NaH}_{2} \mathrm{PO}_{4}, \mathrm{Na}_{2} \mathrm{HPO}_{4}, \mathrm{Na}_{3} \mathrm{PO}_{4}$;

- $\mathrm{K}_{2} \mathrm{CO}_{3}, \mathrm{Na}_{2} \mathrm{CO}_{3}, \mathrm{Rb}_{2} \mathrm{CO}_{3}, \mathrm{Cs}_{2} \mathrm{CO}_{3}$;

- $\mathrm{Na}_{2} \mathrm{SO}_{4}, \mathrm{Cs}_{2} \mathrm{SO}_{4},\left(\mathrm{NH}_{4}\right)_{2} \mathrm{SO}_{4}, \mathrm{MnSO}_{4}, \mathrm{ZnSO}_{4}, \mathrm{MgSO}_{4}$, $\mathrm{CdSO}_{4}, \mathrm{NiSO}_{4}, \mathrm{CoSO}_{4}, \mathrm{Al}_{2}\left(\mathrm{SO}_{4}\right)_{3}$;

$-\mathrm{Na}_{2} \mathrm{~S}_{2} \mathrm{O}_{3}$;

- $\mathrm{KNO}_{3}, \mathrm{NH}_{4} \mathrm{NO}_{3}$;

- KF, NaF;

- $\mathrm{CsCl}$;

- $\mathrm{K}_{3} \mathrm{SbS}_{4}, \mathrm{Na}_{3} \mathrm{SbS}_{4}$;

- $\mathrm{KOH}, \mathrm{NaOH}$;

- potassium citrate, sodium citrate, ammonium citrate;

- dipotassium tartrate, potassium-sodium tartrate.

Data analysis showed, of the number of anions, chloride anions are the least active with respect to the layering of aqueous ethanol-electrolyte systems. For them only the aqueous ethanol $+\mathrm{CsCl}$ system can be layered.

Phosphates, carbonates, thioantimonates are the most active in the process of layering, as they layer both aqueous methanol-electrolyte and aqueous ethanolelectrolyte systems.

Acceptable cations for aqueous ethanol-electrolyte systems, as can be seen, depend on anions. For most anions, only alkali metal cations (including $\mathrm{K}^{+}, \mathrm{Na}^{+}$, in some cases $\mathrm{Rb}^{+}, \mathrm{Cs}^{+}$) are used. But for sulfates, nitrates and citrates, ammonium cation is also applied, and only for sulfates, 6 cations $(2+)$ and cation $\mathrm{Al}^{3+}$ are used in addition. Consequently, sulfates differ markedly from all other anions in relation to acceptable cations.

Apparently, the obtained results can be explained by the fact that methanol is a more polar solvent than ethanol, and the solubility of salts and bases in it is usually higher than in ethanol. This is probably the reason that a noticeably smaller number of electrolytes gives two-phase systems for aqueous methanol than for aqueous ethanol.

Based on the results of a literature search, it was concluded that for membraneless FCs based on immiscible liquids, only three strongly alkaline twophase ethanol-electrolyte-water systems can be used:

$-\mathrm{EtOH}+\mathrm{K}_{2} \mathrm{CO}_{3}+\mathrm{H}_{2} \mathrm{O}$,

$-\mathrm{EtOH}+\mathrm{K}_{3} \mathrm{PO}_{4}+\mathrm{H}_{2} \mathrm{O}$,

$-\mathrm{EtOH}+\mathrm{KOH}+\mathrm{H}_{2} \mathrm{O}$.

Therefore, the conditions for the layering of these systems were investigated.

\section{Materials and methods}

To study the layering conditions in these systems, binodal curves were plotted based on experimental data. To plot them, the cloud point method was used, in which aqueous electrolyte solutions are titrated with ethanol to cause a cloudiness, which indicates the appearance of two liquid phases, it was first described in [6]. In the calculations, the content of main substance and water in electrolyte and the water content in ethanol were taken into account.

To plot the EtOH $+\mathrm{K}_{2} \mathrm{CO}_{3}+\mathrm{H}_{2} \mathrm{O}$ binodal curve, potassium carbonate (chemically pure) containing $99.7 \%$ of $\mathrm{K}_{2} \mathrm{CO}_{3}$, and ethanol containing $4.0 \%$ of water were used. The experiments were carried out at a temperature of $(20 \pm 1){ }^{\circ} \mathrm{C}$. The results of binodal plotting experiments for this system are given in Table 1.

To plot the $\mathrm{EtOH}+\mathrm{K}_{3} \mathrm{PO}_{4}+\mathrm{H}_{2} \mathrm{O}$ binodal curve, potassium phosphate 7-hydrate (pure for analysis) containing $99.5 \%$ of $\mathrm{K}_{3} \mathrm{PO}_{4} \cdot 7 \mathrm{H}_{2} \mathrm{O}$ (i.e. $62.4 \%$ of anhydrous $\mathrm{K}_{3} \mathrm{PO}_{4}$ ) and ethanol containing $4.0 \%$ of water were used. The experiments were carried out at a temperature of $(20 \pm 1){ }^{\circ} \mathrm{C}$. The results of binodal plotting experiments for this system are given in Table 2 .

To plot the $\mathrm{EtOH}+\mathrm{KOH}+\mathrm{H}_{2} \mathrm{O}$ binodal curve, potassium hydroxide (chemically pure) containing $90.0 \%$ of $\mathrm{KOH}$, and ethanol containing $4.0 \%$ of water were used. The experiments were carried out at a temperature of $(20 \pm 1){ }^{\circ} \mathrm{C}$. The data were obtained by the cloud point method with the following modifications:

- points 1-7 -by addition of ethanol to aqueous potassium hydroxide solutions to form two-phase systems, and by following titration of these systems with ethanol to disappear a cloudiness, which indicates the transition to one-phase system;

- points 8-11 -by addition of ethanol to aqueous potassium hydroxide solutions to form two-phase systems, and by following titration of these systems with 
water to disappear a cloudiness, which indicates the transition to one-phase system;

- points 12-15 - by titration of aqueous potassium hydroxide solutions with ethanol to cause a cloudiness, which indicates the appearance of two liquid phases.

The results of binodal plotting experiments for this system are given in Table 3 .

\section{Results and Discussion}

Table 1. Results of binodal plotting experiments for the EtOH $+\mathrm{K}_{2} \mathrm{CO}_{3}+\mathrm{H}_{2} \mathrm{O}$ system.

\begin{tabular}{|c|c|c|c|}
\hline $\begin{array}{c}\text { Sr. } \\
\text { № }\end{array}$ & EtOH, \% m/m & $\mathbf{K}_{\mathbf{2}} \mathbf{C O}_{\mathbf{3}}, \mathbf{\%} \mathbf{~ m} / \mathbf{m}$ & $\mathbf{H}_{\mathbf{2}} \mathbf{O}, \mathbf{\%} \mathbf{~ m} / \mathbf{m}$ \\
\hline 1 & 74.69 & 0.27 & 25.03 \\
\hline 2 & 71.97 & 0.33 & 27.70 \\
\hline 3 & 63.37 & 0.83 & 35.80 \\
\hline 4 & 56.29 & 1.65 & 42.06 \\
\hline 5 & 50.71 & 2.44 & 46.85 \\
\hline 6 & 43.40 & 4.09 & 52.51 \\
\hline 7 & 37.59 & 5.92 & 56.49 \\
\hline 8 & 31.11 & 8.67 & 60.23 \\
\hline 9 & 23.92 & 12.51 & 63.56 \\
\hline 10 & 16.97 & 16.74 & 66.28 \\
\hline 11 & 11.00 & 21.17 & 67.83 \\
\hline 12 & 6.40 & 25.82 & 67.79 \\
\hline 13 & 3.82 & 30.01 & 66.17 \\
\hline 14 & 2.31 & 34.03 & 63.66 \\
\hline 15 & 1.52 & 38.16 & 60.32 \\
\hline 16 & 0.67 & 42.34 & 56.99 \\
\hline 17 & 0.52 & 46.21 & 53.27 \\
\hline
\end{tabular}

Binodal curve for the $\mathrm{EtOH}+\mathrm{K}_{2} \mathrm{CO}_{3}+\mathrm{H}_{2} \mathrm{O}$ system according to data of Table 1 is presented in Fig. 1, in Fig. 2 it is given in comparison with literature data obtained by both the cloud point method and the equilibrium phase method $[9,16,20]$. Comparison of experimental data with the results of other authors showed that they are consistent.

Binodal curve for the $\mathrm{EtOH}+\mathrm{K}_{3} \mathrm{PO}_{4}+\mathrm{H}_{2} \mathrm{O}$ system according to data of Table 2 is presented in Fig. 3, in Fig. 4 it is given in comparison with literature data obtained by the cloud point method too [18, 20]. Comparison of experimental data with the results of other authors showed that they are consistent.

Binodal curve for the $\mathrm{EtOH}+\mathrm{KOH}+\mathrm{H}_{2} \mathrm{O}$ system according to data of Table 3 is presented in Fig. 5, in Fig. 6 it is given in comparison with literature data [13, 21]. No other works for this system have been found in the literature. It should be noted that the equilibrium phase method was used in these works, i.e. the cloud point method has not been previously applied to this system.

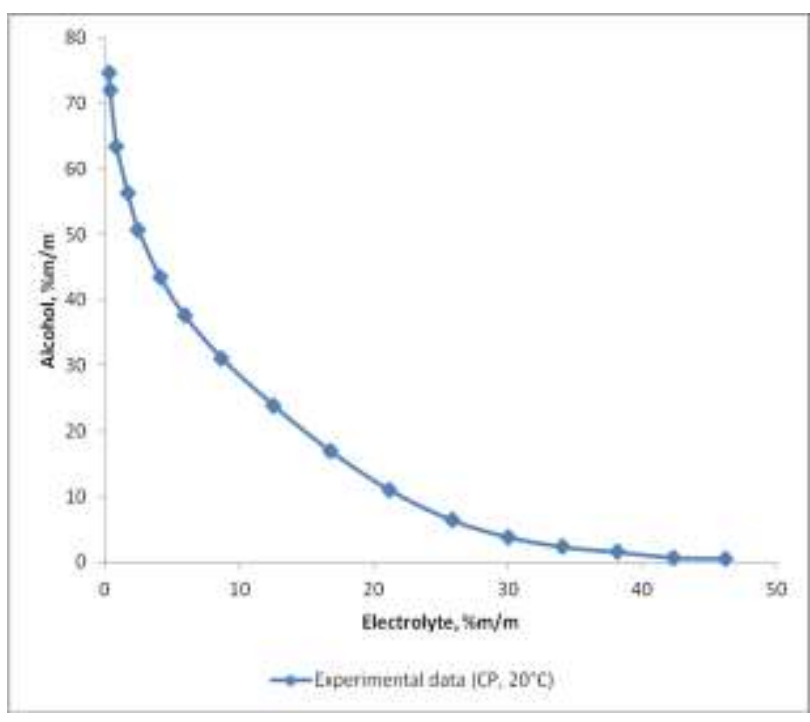

Fig. 1. Binodal curve for the $\mathrm{EtOH}+\mathrm{K}_{2} \mathrm{CO}_{3}+\mathrm{H}_{2} \mathrm{O}$ system according to experimental data (Table 1). $\mathrm{CP}$ - cloud point method.

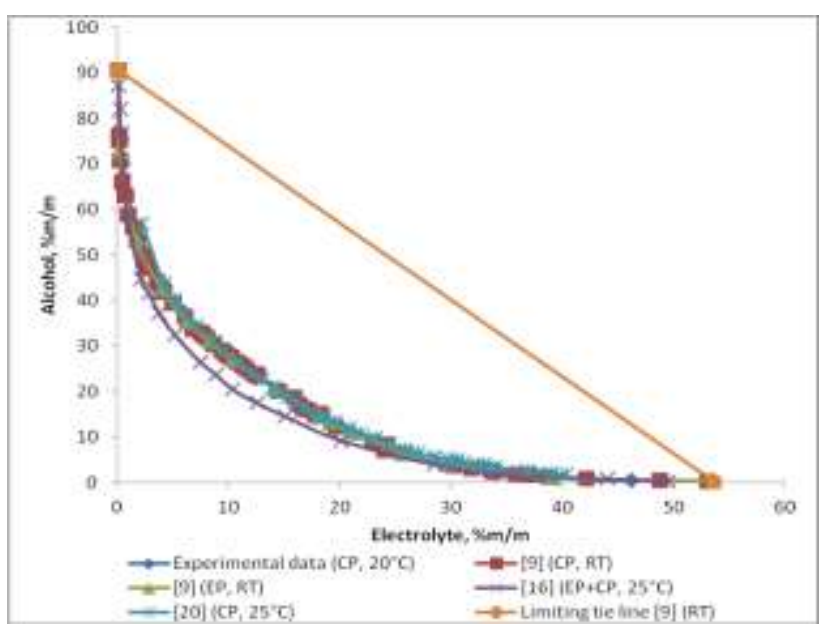

Fig. 2. Binodal curves for the $\mathrm{EtOH}+\mathrm{K}_{2} \mathrm{CO}_{3}+\mathrm{H}_{2} \mathrm{O}$ system. Experimental data in comparison with literature data $[15,19$, 20]; $\mathrm{CP}$ - cloud point method, EP - equilibrium phase method; $\mathrm{RT}$ - room temperature $(22-25)^{\circ} \mathrm{C}$. 
Table 2. Results of binodal plotting experiments for the $\mathrm{EtOH}$ $+\mathrm{K}_{3} \mathrm{PO}_{4}+\mathrm{H}_{2} \mathrm{O}$ system.

\begin{tabular}{|c|c|c|c|}
\hline $\begin{array}{c}\text { Sr. } \\
\text { № }\end{array}$ & $\begin{array}{c}\text { EtOH, } \% \\
\mathbf{m} / \mathbf{m}\end{array}$ & $\begin{array}{c}\mathbf{K}_{\mathbf{3}} \mathbf{P O}_{\mathbf{4}}, \mathbf{\%} \mathbf{\%} \\
\mathbf{m} / \mathbf{m}\end{array}$ & $\mathbf{H}_{\mathbf{2}} \mathbf{O}, \mathbf{\%} \mathbf{~ m} / \mathbf{m}$ \\
\hline 1 & 58.33 & 0.62 & 41.06 \\
\hline 2 & 55.42 & 0.87 & 43.71 \\
\hline 3 & 47.83 & 1.85 & 50.32 \\
\hline 4 & 39.13 & 3.84 & 57.03 \\
\hline 5 & 33.64 & 5.82 & 60.54 \\
\hline 6 & 29.81 & 7.63 & 62.56 \\
\hline 7 & 25.56 & 9.95 & 64.49 \\
\hline 8 & 21.91 & 12.41 & 65.69 \\
\hline 9 & 17.34 & 15.66 & 66.99 \\
\hline 10 & 12.83 & 19.17 & 68.00 \\
\hline 11 & 9.10 & 23.22 & 67.68 \\
\hline 12 & 5.47 & 27.29 & 67.24 \\
\hline 13 & 3.47 & 31.19 & 65.34 \\
\hline 14 & 2.56 & 34.69 & 62.75 \\
\hline 15 & 2.05 & 38.35 & 59.60 \\
\hline 16 & 1.21 & 43.40 & 55.39 \\
\hline 17 & 1.00 & 48.12 & 50.88 \\
\hline
\end{tabular}

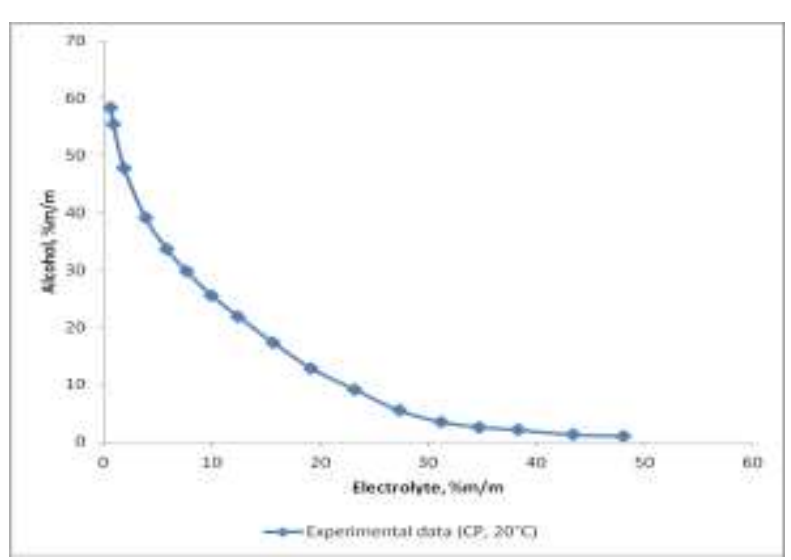

Fig. 3. Binodal curve for the $\mathrm{EtOH}+\mathrm{K}_{3} \mathrm{PO}_{4}+\mathrm{H}_{2} \mathrm{O}$ system according to experimental data (Table 2). $\mathrm{CP}$ - cloud point method.

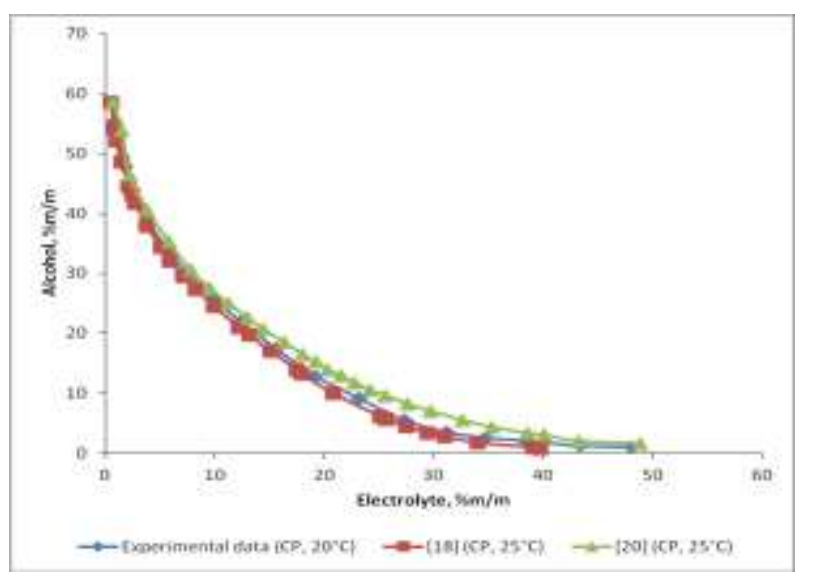

Fig. 4. Binodal curves for the $\mathrm{EtOH}+\mathrm{K}_{3} \mathrm{PO}_{4}+\mathrm{H}_{2} \mathrm{O}$ system. Experimental data in comparison with literature data [6, 20]; $\mathrm{CP}$ - cloud point method.

When comparing binodal curves in Fig. 3, it must be taken into account that they were obtained at different temperatures: $17{ }^{\circ} \mathrm{C}$ for [21], $20^{\circ} \mathrm{C}$ for our work, and 30 ${ }^{\circ} \mathrm{C}$ for [13]. The temperature dependence of the binodal curves is clearly visible for this system, and the binodal curve obtained by us is between the curve according to [21] and the curve according to [13]. The shapes of all three binodal curves are similar; therefore the binodal curve obtained by us is correct.

Table 3. Results of bimodal plotting experiments for the EtOH $+\mathrm{KOH}+\mathrm{H}_{2} \mathrm{O}$ system.

\begin{tabular}{|c|c|c|c|}
\hline Sr.No & $\begin{array}{c}\text { EtOH, } \% \\
\mathbf{m} / \mathbf{m}\end{array}$ & $\begin{array}{c}\mathbf{K O H}, \mathbf{\%} \\
\mathbf{m} / \mathbf{m}\end{array}$ & $\mathbf{H}_{\mathbf{2}} \mathbf{O}, \mathbf{\%} \mathbf{~ m} / \mathbf{m}$ \\
\hline 1 & 55.79 & 24.98 & 19.23 \\
\hline 2 & 54.10 & 24.03 & 21.86 \\
\hline 3 & 52.25 & 23.04 & 24.71 \\
\hline 4 & 47.08 & 22.35 & 30.58 \\
\hline 5 & 42.47 & 22.53 & 35.00 \\
\hline 6 & 33.80 & 24.17 & 42.03 \\
\hline 7 & 31.29 & 24.88 & 43.83 \\
\hline 8 & 25.92 & 26.27 & 47.81 \\
\hline 9 & 22.19 & 27.74 & 50.06 \\
\hline 10 & 18.00 & 29.34 & 52.66 \\
\hline 11 & 12.43 & 31.07 & 56.50 \\
\hline 12 & 6.72 & 34.32 & 58.96 \\
\hline 13 & 5.65 & 35.12 & 59.24 \\
\hline 14 & 3.03 & 39.13 & 57.84 \\
\hline 15 & 1.84 & 43.01 & 55.15 \\
\hline
\end{tabular}

Further analysis of two-phase systems showed that of the systems studied by us: $\mathrm{EtOH}+\mathrm{K}_{2} \mathrm{CO}_{3}+\mathrm{H}_{2} \mathrm{O}$, EtOH $+\mathrm{K}_{3} \mathrm{PO}_{4}+\mathrm{H}_{2} \mathrm{O}$ and $\mathrm{EtOH}+\mathrm{KOH}+\mathrm{H}_{2} \mathrm{O}$, the first two systems don't have a sufficiently high $\mathrm{pH}$ value. In addition, for the first system, the deposition of potassium carbonate on the surface of the anode is possible, which can lead to blocking of pores and impairment of its operation. Therefore, it was decided to use the third system, i.e. $\mathrm{EtOH}+\mathrm{KOH}+\mathrm{H}_{2} \mathrm{O}$, for the first series of experiments.

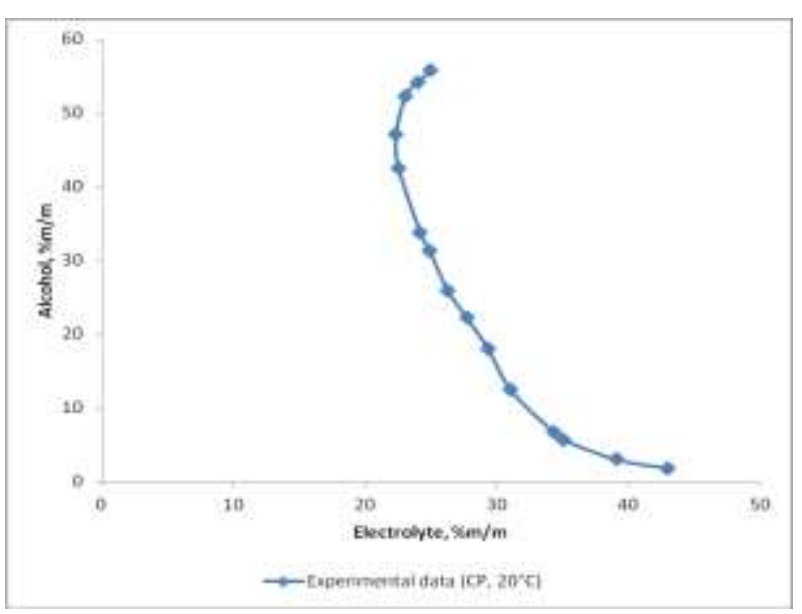

Fig. 5. Binodal curve for the $\mathrm{EtOH}+\mathrm{KOH}+\mathrm{H}_{2} \mathrm{O}$ system according to experimental data (Table 3 ). $\mathrm{CP}$ - cloud point method. 


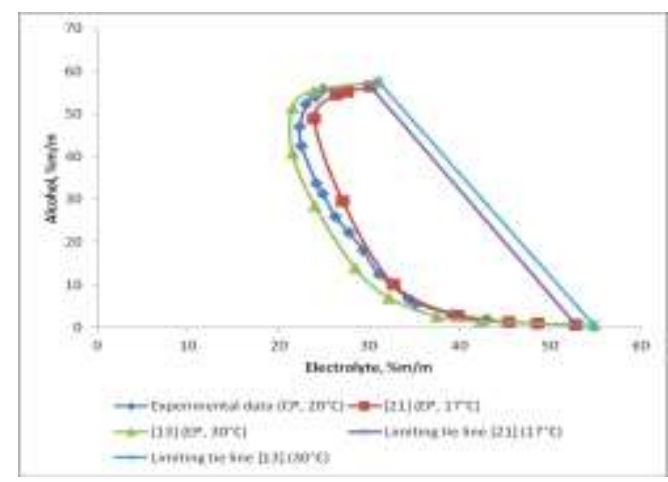

Fig. 6. Binodal curves for the $\mathrm{EtOH}+\mathrm{KOH}+\mathrm{H}_{2} \mathrm{O}$ system. Experimental data in comparison with literature data $[13,21]$; $\mathrm{CP}$ - cloud point method, EP - equilibrium phase method.

When choosing the specific composition of this twophase system, i.e. a point in the region of two-phase systems, it is advisable to use points located in the middle of the region of two-phase systems, near the line connecting the middle points of the tie lines, since in this case the masses of the top and bottom phases will be close.

It is desirable that the selected point is located to the right as far as possible - the righter the point is located, the lower the ethanol content in the bottom phase, however, it cannot be to the right of the limiting tie line, on which the two-phase liquid system is in equilibrium with the solid electrolyte.

The following point of the two-phase system corresponds to both of the above requirements: EtOH $30 \% \mathrm{~m} / \mathrm{m} ; \mathrm{KOH}-40 \% \mathrm{~m} / \mathrm{m} ; \mathrm{H}_{2} \mathrm{O}-30 \% \mathrm{~m} / \mathrm{m}$. This system was taken as the basis for studies of FCs based on two immiscible liquids.

Further studies showed that this system is separated into two phases. The composition of the ethanol (top) phase: $\mathrm{EtOH}-57 \% \mathrm{~m} / \mathrm{m}, \mathrm{KOH}-28 \% \mathrm{~m} / \mathrm{m}, \mathrm{H}_{2} \mathrm{O}-15$ $\% \mathrm{~m} / \mathrm{m}, \mathrm{pH} 13.1$. The composition of the aqueous (bottom) phase: $\mathrm{EtOH}-\sim 0 \% \mathrm{~m} / \mathrm{m}, \mathrm{KOH}-50 \% \mathrm{~m} / \mathrm{m}$, $\mathrm{H}_{2} \mathrm{O}-50 \% \mathrm{~m} / \mathrm{m}, \mathrm{pH} 13.2$.

Thus, the selected system of immiscible liquids has all the necessary properties for the studied type of FCs: - two phases aren't mixed;

- both phases have electrical conductivity;

- the top phase have the maximum content of ethanol, the bottom phase have the minimum content of ethanol.

A further area of research lies in the field of optimizing the composition of both phases, studying the processes of mass transfer in these systems and their physicochemical characteristics.

\section{Conclusion}

As a result of the studies, binodal curves were plotted to determine the phase separation conditions in the systems $\mathrm{EtOH}+\mathrm{K}_{2} \mathrm{CO}_{3}+\mathrm{H}_{2} \mathrm{O}$, EtOH $+\mathrm{K}_{3} \mathrm{PO}_{4}+\mathrm{H}_{2} \mathrm{O}$ and $\mathrm{EtOH}$ $+\mathrm{KOH}+\mathrm{H}_{2} \mathrm{O}$, and a system was selected for a new type of membraneless FCs using ethanol.

It was revealed that the following two-phase system meets the required conditions: $\mathrm{EtOH}-30 \% \mathrm{~m} / \mathrm{m} ; \mathrm{KOH}$ $-40 \% \mathrm{~m} / \mathrm{m} ; \mathrm{H}_{2} \mathrm{O}-30 \% \mathrm{~m} / \mathrm{m}$, for which the $\mathrm{EtOH}$ content in the top phase is $57 \% \mathrm{~m} / \mathrm{m}$, in the bottom phase is $\sim 0 \% \mathrm{~m} / \mathrm{m}$.

The studies were carried out with the financial support of the Russian Foundation for Basic Research (RFBR) in the framework of the scientific project No. 19-58-60002.

\section{References}

[1] S.I. Kozlov, V.N. Fateev, Transport on alternative fuel, 3, 41-50 (2016).

[2] M.R. Tarasevich, A.V. Kuzov, Alternative energy and ecology, 7, 86-108 (2010).

[3] R. Ferrigno, A.D. Stroock, T.D. Clark, M. Mayer, G.M. Whitesides, J. Amer. Chem. Soc., 124, 12930-12931 (2002).

[4] M.-A. Goulet, E. Kjeang, J. Power Sources, 260, 186-196 (2014).

[5] I.H. Hanapi, S.K. Kamarudin, A.M. Zainoodin, U.A. Hasran, Int. J. Energy Res., 43, 8956-8972 (2019).

[6] C.E. Linebarger, Amer. Chem. J., 14, 380-398 (1892).

[7] M.G. Freire, C.M.S.S. Neves, P.J. Carvalho, R.L. Gardas, A.M. Fernandes, I.M. Marrucho, L.M.N.B.F. Santos, J.A.P. Coutinho, J. Phys. Chem. B., 111, 13082-13089 (2007).

[8] A.D. Donk, Chem. Weekblad, 5, 629-645 (1908).

[9] G.B. Frankforter, F.C. Frary, J. Phys. Chem., 17, 402-473 (1913).

[10] I.A.O. Reis, S.B. Santos, L.A. Santos, N. Oliveira, M.G. Freire, J.F.B. Pereira, S.P.M. Ventura, J.A.P. Coutinho, C.M.F. Soares, Á.S. Lima, Food Chem., 135, 2453-2461 (2012).

[11] N. Dodge, L.C. Graton, J. Phys. Chem., 2, 498501 (1898).

[12] A.D. Donk, Chem. Weekblad, 5, 629-645 (1908).

[13] A.J.C. de Waal, Evenwichten in quaternaire systemen waarin twee vloeistof-phasen optreden. Dissertation, Leiden (1910).

[14] A. Seidell, Public Health and Marine-Hospital Service of the United States, Hygienic Laboratory, Bulletin, Washington, Government Printing Office, 67 (1910).

[15] M.-C. Hu, M. Meng, S.-Y. Gao, Z.-H. Liu, S.-P. Xia, Chem. J. Chin. Univ., 23, 1219-1222 (2002).

[16] A. Salabat, M. Hashemi, J. Chem. Eng. Data., 51, 1194-1197 (2006).

[17] D.H. Dagade, R.R. Kumbhar, S.R. Sabale, K.J. Patil, Fluid Phase Equilibr., 255, 110-114 (2007).

[18] Y. Wang, Y. Mao, J. Han, Y. Liu, Y. Yan, J. Chem. Eng. Data., 55, 5621-5626 (2010).

[19] Y. Wang, Y. Mao, J. Han, Y. Liu, J. Chem. Eng. Data., 56, 622-626 (2011).

[20] M.O. Toledo, F.O. Farias, L. Igarashi-Mafra, M.R. Mafra, J. Chem. Eng. Data., 64, 2018-2026 (2019).

[21] Guide of Chemistry, 2nd ed. M.-L., Chemistry, 3, 299 (1965). 